DOI:

Cite this as:

Artafanti, Pandia, Weny Savitry S. Description Of Teacher's Knowledge And Attitudes To Individual Learning

Programs. Indonesian Journal of Disability Studies (IJDS).2018: Vol. 5(2): PP 190-199.

\title{
DESCRIPTION OF TEACHER'S KNOWLEDGE AND ATTITUDES TO INDIVIDUAL LEARNING PROGRAMS
}

\author{
${ }^{1 *}$ Artafanti, ${ }^{2}$ Weny Savitry S. Pandia \\ ${ }^{1,2}$ Magister Profesi Psikologi Pendidikan Universitas Katolik Indonesia Atma Jaya Jakarta
}

\begin{abstract}
The learning of the Sekolah Luar Biasa (SLB) focused on the diversity of abilities and potential of students. This need can be facilitated by modifying the curriculum based on assessment of students, which is then used as the basis for making the Program Pembelajaran Individu (PPI). The study was conducted on Jakarta SLBN $\mathrm{X}$ teachers who began to modify the curriculum, but were not yet maximal. The study uses quantitative methods with qualitative data as supporting data. Quantitative data was obtained through measuring instruments of knowledge and attitudes towards the making of PPIs filled by 29 teachers. While qualitative data was obtained through interviews with nine teachers based on the results of quantitative data categorization (lacking, sufficient, good). The results showed that $34 \%$ had insufficient knowledge, $59 \%$ were sufficient, and $7 \%$ were good about making PPIs. While $45 \%$ of teachers have a lack of attitude and are quite positive, and $10 \%$ of teachers are categorized as good in their attitude towards making PPIs. Different tests show there are differences in the attitudes of teachers who have and have never attended workshops on handling students with special needs. Qualitative data shows that the factors that play a role in making PPI are lack of knowledge of teachers in making PPIs, regulations in schools that have not required the making of PPIs, and lack of time to prepare PPIs.
\end{abstract}

Keywords: Program Pembelajaran Individu, extraordinary school teacher knowledge, attitudes of exceptional school teachers, extraordinary schools

\section{Pendahuluan}

Hak mendapat pendidikan diatur dalam UU nomor 20 tahun 2003 yang menyatakan bahwa setiap anak tanpa terkecuali berhak mendapatkan akses pendidikan, termasuk anak berkebutuhan khusus. Hal ini diimplementasikan dengan pemberian layanan pendidikan khusus, yang juga berfokus pada kemampuan fungsional siswa (Thompson, dkk, 2013; Mangunsong, 2009). Salah satu bentuk layanan formal pendidikan khusus adalah Sekolah Luar Biasa (SLB).

Seperti halnya keberadaan sekolah formal reguler, SLB diharapkan mampu memberikan akses dan kesempatan pendidikan yang setara bagi anak berkebutuhan khusus. Dalam proses belajar

* Corresponding author: Artafanti

arta.fanti@gmail.com

Published online at http://IJDS.ub.ac.id/

Copyright $@ 2018$ PSLD UB Publishing. All Rights Reserved di sekolah, setiap siswa memiliki kemampuan dan keunikan beragam. Hal ini didukung oleh Pernyataan Salamanca yang dirumuskan UNESCO mengenai "Pendidikan untuk Semua". Salah satu isi pernyataan ini menunjukkan bahwa setiap anak memiliki keberagaman yang luas dalam karakteristik dan kebutuhannya. Oleh sebab itu, sistem pendidikan diharapkan dapat mendesain program yang dapat mewujudkan keberagaman tersebut (Pernyataan Salamanca, 1994). Terkait dengan hal ini, maka guru sangat perlu mengakomodasi semua peserta didik, termasuk peserta didik yang berada di SLB.

Sejalan dengan hal tersebut, Peraturan Dirjen Pendidikan Dasar dan Menengah (Dikdasmen) nomor 10 tahun 2017, yang membahas mengenai penggunaan kurikulum 2013, menegaskan perlunya fasilitas bagi keragaman siswa SLB. Hal ini mengarah pada kompetensi dasar yang tertuang di Kurikulum 2013 yang 
DOI:

sangat fleksibel dan dapat disesuaikan dengan kondisi siswa. Oleh karena itu, pembelajaran harus didasarkan pada hasil asesmen yang kemudian menjadi dasar pembelajaran setiap siswa. Salah satu sistem layanan pembelajaran yang dapat mengakomodasi peserta didik sesuai dengan kondisinya ini adalah dengan pembuatan Program Pembelajaran Individual (PPI).

PPI merupakan sebuah program pembelajaran yang disesuaikan dengan kebutuhan dasar masing-masing peserta didik. Pada dasarnya PPI merupakan program pembelajaran yang disusun dan dikembangkan menjadi sebuah program berdasarkan hasil asesmen terhadap kemampuan setiap siswa. Mercer dan Mercer (1989) menyatakan bahwa sekolah yang memiliki PPI sebagai program bagi siswanya merupakan sekolah yang bersifat lebih inklusif dibandingkan sekolah yang tidak menggunakan PPI. Adanya PPI di sekolah dapat membantu guru mewujudkan sistem dan metode pembelajaran yang sesuai dengan kemampuan masing-masing siswa.

Dengan pemberian materi/stimulasi yang tepat, siswa menjadi lebih termotivasi dalam pembelajaran dan hal ini akan meningkatkan performa belajar siswa (Rudiyati, 2010). Hasil penelitian Arravey yang tercatat oleh Lynch pada tahun 1994 mengenai efektivitas PPI bagi siswa berkebutuhan khusus menunjukkan bahwa kelompok eksperimen pada 32 orang anak dengan PPI secara signifikan memiliki ketertarikan dalam belajar yang lebih tinggi dibandingkan dengan kelompok kontrol. Hal ini menunjukkan bahwa proses pembelajaran yang didasarkan kepada masalah dan kebutuhan anak seperti yang dikehendaki dalam PPI lebih membantu tercapainya tujuan pembelajaran anak berkebutuhan khusus.

Saat ini masih terdapat hambatan yang ditemui guru dalam menerapkan PPI. Hasil studi Rahmawati (2015) mengenai program pengembangan kompetensi guru salah satu SLB di Bandung menunjukkan bahwa kesulitan terletak pada masih belum terbiasanya para guru di SLB tersebut dalam membuat PPI. Guru cenderung belum menganggap PPI sebagai salah satu komponen yang penting dalam melayani peserta didik. Selain itu, masih terdapat guru yang kurang paham untuk membuat PPI, sehingga muncul kebingungan dan rasa malas untuk membuatnya. Hal ini juga sejalan dengan hasil penelitian
Rochyadi (2001) mengenai penerapan PPI di SLB C yang dilakukan terhadap 104 guru SLB di Bandung. Hanya $1,28 \%$ guru yang mengimplementasikan pengetahuannya pada tahap orientasi PPI ketika berpraktek secara profesional sebagai guru dalam kesehariannya.

Dampak dari terhambatnya penerapan PPI ini adalah guru cenderung menggunakan metode klasikal dalam pembelajaran. Tidak jarang guru juga hanya bekerja berdasarkan pencapaian tujuan kurikulum semata, tanpa memperhatikan kebutuhan dan kemampuan masing-masing peserta didik (Nurlaila, 2015). Salah satu SLB Negeri di Jakarta yang masih memiliki hambatan dalam pembuatan PPI adalah SLBN X Jakarta yang menerima siswa tunarungu dan tunagrahita.

Sejak tahun ajaran 2017/2018, guru-guru di SLBN $X$ Jakarta sudah mulai mengimplementasikan pembuatan PPI dengan melakukan modifikasi Rencana Program Pembelajaran (RPP). Hasil studi menunjukkan bahwa guru langsung mempraktekkan cara mengajar berdasarkan hasil terkaannya terhadap kemampuan siswa. Tidak sedikit guru yang menerka rencana pembelajaran untuk peserta didiknya tanpa basis asesmen yang dapat dipertanggungjawabkan. Data penelitian awal menunjukkan bahwa guru tidak memahami cara memodifikasi kurikulum sesuai kondisi anak. Mereka mencoba memberikan RPP yang dimodifikasi kepala sekolah, namun hasil yang diberikan tidak sesuai dengan harapan dan pemahaman mengenai modifikasi kurikulum. Ketika diberikan kesempatan untuk memperbaiki kesalahan, beberapa guru cenderung menolak memberikan revisi RPP tersebut.

Sebagian besar guru pernah mengikuti workshop/bimbingan teknis bertemakan siswa dengan kebutuhan khusus, yang sebagian besar berfokus pada perkembangan siswa secara individu. Selain itu, status guru juga sudah tersertifikasi, sehingga seharusnya pelaksanaan PPI telah mengutamakan keberagaman siswa. Situasi ini dapat terjadi karena minimnya pengetahuan guru mengenai PPI. Jika guru memiliki kemampuan membuat PPI, guru dapat merasakan manfaat penggunaan PPI, dan tidak hanya bergantung pada RPP. Fabrigar (2005) menemukan bahwa sikap yang berdasar pada pengetahuan yang tinggi merupakan prediktor tertinggi perilaku seseorang dalam lingkungannya. 
DOI:

Dengan demikian, jika dikaitkan dengan situasi para guru di SLBN X, dengan diketahuinya tingkat pengetahuan mengenai pembuatan PPI, maka dapat diketahui pula prediksi sikap dan perilaku guru. Oleh karena itu, kajian mengenai pengetahuan dan sikap guru mengenai PPI dibutuhkan agar perilaku pembuatan PPI dapat muncul dan bertahan lebih lama sesuai dengan yang diharapkan pada pelaksanaan kurikulum 2013 bagi siswa berkebutuhan khusus.

Pengetahuan merupakan domain yang sangat penting dalam membentuk tindakan seseorang (Notoatmodjo, 2003). Bloom mengklasifikasikan aspek pengetahuan ke dalam tiga kelompok yaitu pertama istilah dan fakta; kedua pengetahuan tentang cara untuk menangani masalah-masalah khusus yang meliputi kebiasaan, kecenderungan, klasifikasi, kategori, dan metode; dan ketiga yaitu pengetahuan mengenai kaidah yang bersifat universal yang meliputi prinsip, teori, dan struktur (Wawan dan Dewi, 2010).

Sementara itu, sikap merupakan evaluasi yang dilakukan seseorang terhadap orang, objek, dan ide. Hal ini berkaitan dengan kesiapan atau kesediaan untuk bertindak, dan bukan merupakan pelaksanaan motif tertentu (Aronson, 2007; Newcomb dalam Notoatmodjo, 2003). Sikap yang positif memiliki kecenderungan untuk mendekati, menyenangi, dan mengharapkan obyek tertentu; sedangkan sikap negatif memiliki kecenderungan untuk menjauhi, menghindari, membenci, dan tidak menyukai obyek tertentu. Eagly dan Chaiken (dalam Wawan, 2010) menyatakan bahwa sikap dapat diposisikan sebagai hasil evaluasi terhadap objek yang diekspresikan ke dalam proses-proses kognitif, afektif, dan perilaku/konatif. Evaluasi kognitif berkaitan dengan keyakinan serta pengetahuan mengenai objek, orang, dan ide. Evaluasi afektif berhubungan dengan suka atau tidaknya seseorang terhadap objek tersebut, sementara evaluasi perilaku merupakan kecenderungan untuk bereaksi tertentu terhadap objek yang dimaksud.

Berdasarkan uraian yang berkaitan dengan pengetahuan dan sikap guru secara umum dalam pembuatan PPI serta kondisi SLBN X Jakarta saat ini, perlu dikaji lebih lanjut mengenai pengetahuan dan sikap guru SLBN X dalam penerapan PPI. Penelitian ini dilakukan guna mendapatkan gambaran mengenai pengetahuan dan sikap guru yang dilihat secara kognitif, afektif, dan konatif terkait dengan penerapan PPI di SLBN X. Secara keseluruhan, hasil penelitian diharapkan dapat memberi gambaran terkait pengetahuan dan sikap guru dalam penerapan PPI saat ini. Lebih jauh, akan diketahui pula faktor pendukung dan penghambat yang mempengaruhi penerapannya. Hasil penelitian ini akan digunakan sebagai dasar pembuatan intervensi yang sesuai dengan kondisi guru saat ini dan diharapkan dapat membantu guru meningkatkan pengetahuan dan sikapnya dalam mengaplikasikan PPI bagi peserta didik dengan kebutuhan khusus.

\section{Metode Penelitian}

Penelitian ini merupakan penelitian deskriptif yang juga termasuk ke dalam jenis penelitian terapan (applied research). Hasil penelitian mengenai pengetahuan dan sikap guru terkait penerapan PPI ini, akan dijadikan sebagai analisis kebutuhan pelaksanaan intervensi, sehingga nantinya intervensi dapat dirancang sesuai dengan aspek yang dibutuhkan. Metode yang digunakan dalam penelitian ini adalah Explanatory Sequential Mixed Method Design, yaitu metode penelitian kuantitatif dengan menyertakan data kualitatif sebagai pendukung (Creswell, 2014).

\section{Data Kuantitatif}

Populasi penelitian adalah guru SLB di Jakarta dengan teknik pengambilan sampel nonprobability sampling sehingga seluruh guru yang berjumlah 29 orang menjadi sampel penelitian ini. Alat ukur penelitian kuantitatif disusun berdasarkan definisi pengetahuan dan sikap terhadap pembuatan PPI. Alat Ukur Pengetahuan mengenai PPI berjumlah 16 item, disusun untuk mengetahui pemahaman guru mengenai prinsip dasar PPI, tujuan pembuatan PPI, serta tahapan-tahapan yang berguna bagi pembuatan PPI. Tahapan ini termasuk pada pengetahuan guru dalam melakukan asesmen, bekerjasama dengan pihak-pihak lain yang berkaitan dengan siswa, hingga pengetahuan rinci mengenai komponen-komponen yang perlu dituliskan dalam pembuatan PPI bagi siswa.

Alat Ukur Sikap terhadap PPI disusun untuk menggali evaluasi yang dilakukan seseorang terhadap orang, objek, dan ide dalam pembuatan PPI. Hal ini diukur dari 78 butir pernyataan yang 
DOI:

mencakup bagaimana guru mengeluarkan pemikiran (kognitif), perasaan (afektif), dan kecenderungannya dalam bertindak (praktik) terkait dengan keberadaan PPI dan proses pembuatannya.

Uji validitas alat ukur dilakukan dengan menggunakan teknik content validity dan construct validity. Content validity dilakukan dengan face validity atau uji keterbacaan kepada beberapa guru untuk memastikan apakah setiap item alat ukur dapat dimengerti dan sudah layak digunakan dalam konteks guru di SLBN X Jakarta. Construct validity pada alat ukur pengetahuan dilakukan dengan menggunakan metode korelasi point biserial, yang menunjukkan bahwa setiap item pada alat ukur berada pada rentang skor .261 hingga .654 Reliabilitas alat ukur diukur dengan metode KR 20 dan mendapatkan skor .841. Pada alat ukur sikap, construct validity dilakukan dengan menggunakan metode internal consistency untuk mengetahui validitas setiap item. Teknik yang digunakan adalah pearson product moment corrected item total correlation yang didapatkan melalui perhitungan menggunakan program SPSS 25.0. Dari hasil uji validitas didapatkan bahwa item-item terpakai memiliki koefisien korelasi antara .204 sampai .808 dengan coefficient cronbach alpha sebesar .961.

\section{Data Kualitatif}

Metode pemilihan partisipan data kualitatif dilakukan dengan menggunakan purposiveljudgemental sampling. Secara spesifik, metode yang digunakan adalah maximal variation sampling. Kriteria yang digunakan peneliti untuk pemilihan pratisipan metode kualitatif adalah hasil dari penelitian kuantitatif, yaitu alat ukur tingkat pengetahuan dan sikap guru dalam penerapan PPI. Karakteristik utama partisipan adalah guru SLBN $\mathrm{X}$ Jakarta variasi tingkat pengetahuan kurang, cukup, dan baik, serta guru dengan sikap positif rendah, cukup, dan tinggi terhadap pembuatan PPI. Dari hasil kuantitatif yang didapatkan, terdapat sembilan guru yang memenuhi kriteria dalam syarat variasi tingkat pengetahuan dan sikap. Variasi yang didapatkan adalah pada pengetahuan dan sikap yang cukup-kurang, cukup-cukup, cukup-baik, kurang-kurang, kurang-cukup, dan cukup-baik.
Metode pengumpulan data dilakukan dengan melakukan wawancara individu, dengan menggunakan pedoman terstandar yang terbuka (standardized open-ended interview). Fokus data kualitatif adalah terlebih dahulu dimulai dengan menggali pandangan guru terhadap pembuatan PPI secara keseluruhan. Dilanjutkan dengan menggali data mengenai faktor penghambat dan faktor pendukung mengenai pembuatan PPI di SLBN X Jakarta.

\section{Analisis dan Pembahasan}

\section{Hasil Penelitian Kuantitatif}

Mayoritas partisipan penelitian berjenis kelamin perempuan, diikuti dengan partisipan berjenis kelamin pria sebanyak $31 \%$. Mayoritas partisipan dalam penelitian ini berusia di atas 50 tahun, yaitu sebanyak 17 partisipan. Diikuti dengan partisipan usia 35 hingga 45 tahun sebanyak 8 orang dan partisipan dengan kelompok usia 22 hingga 34 tahun sebanyak 4 orang. Pada rentang usia tersebut didapati bahwa mayoritas partisipan sudah menikah. Terkait dengan tingkatan pendidikan, seluruh partisipan memiliki pendidikan terakhir S1 dengan mayoritas berasal dari Fakultas Pendidikan. 72\% dari seluruh partisipan berasal dari penjurusan Pendidikan Luar Biasa.

Selain itu, berkaitan dengan pengalaman yang dimiliki, 26 partisipan dalam penelitian ini merupakan guru-guru yang memiliki pengalaman mengajar sebelum masuk di SLBN X Jakarta. Sementara 23 guru dari partisipan secara keseluruhan juga memiliki pengalaman mengikuti workshop yang berkaitan dengan pengajaran pada siswa dengan kebutuhan khusus. Dari 29 partisipan penelitian, terdapat 21 partisipan yang telah tersertifikasi dan 8 belum memiliki status sertifikasi. Sementara itu, dapat dilihat pula bahwa 20 guru berstatus guru tetap dan sisanya adalah guru honorer.

Rentang waktu partisipan dalam penelitian mengajar di SLBN X Jakarta berkisar antara 3 bulan hingga lebih dari 10 tahun mengajar. 6 guru telah mengajar selama lebih dari 10 tahun, 15 guru mengajar antara 1 hingga10 tahun, sementara 8 partisipan mengajar kurang dari 1 tahun di SLBN $\mathrm{X}$ Jakarta. Dari data yang dipaparkan, dapat 
DOI:

terlihat bahwa terdapat beragam karakteristik guru yang mengajar di SLBN X Jakarta.

Tabel 1. Data Demografis Partisipan Penelitian

\begin{tabular}{|c|c|c|c|}
\hline Data Demografis & & Frekuensi & $\begin{array}{l}\text { Presentase } \\
(\%)\end{array}$ \\
\hline \multirow[t]{2}{*}{ Jenis Kelamin } & Pria & 9 & $31 \%$ \\
\hline & Wanita & 20 & $69 \%$ \\
\hline \multirow[t]{3}{*}{ Usia } & $22-34$ tahun & 4 & $14 \%$ \\
\hline & $35-45$ tahun & 8 & $28 \%$ \\
\hline & $>45$ tahun & 17 & $59 \%$ \\
\hline \multirow{3}{*}{$\begin{array}{l}\text { Status } \\
\text { Pernikahan }\end{array}$} & Sudah & 28 & $97 \%$ \\
\hline & Menikah & & \\
\hline & $\begin{array}{l}\text { Belum } \\
\text { Menikah }\end{array}$ & 1 & $3 \%$ \\
\hline \multirow{7}{*}{$\begin{array}{l}\text { Pendidikan } \\
\text { Terakhir }\end{array}$} & S1 PLB & 21 & $72 \%$ \\
\hline & $\begin{array}{l}\text { S1 Manajemen } \\
\text { PLB }\end{array}$ & 3 & $10 \%$ \\
\hline & $\begin{array}{l}\text { S1 Bahasa } \\
\text { Indonesia }\end{array}$ & 1 & $3 \%$ \\
\hline & S1 PGSD & 1 & $3 \%$ \\
\hline & S1 Pendidikan & 1 & $3 \%$ \\
\hline & $\begin{array}{l}\text { S1 Pendidikan } \\
\text { Matematika }\end{array}$ & 1 & $3 \%$ \\
\hline & $\begin{array}{l}\text { S1 Bahasa } \\
\text { Inggris }\end{array}$ & 1 & $3 \%$ \\
\hline \multirow{2}{*}{$\begin{array}{l}\text { Pengalaman } \\
\text { Mengajar }\end{array}$} & Ada & 26 & $90 \%$ \\
\hline & Tidak Ada & 3 & $10 \%$ \\
\hline \multirow{2}{*}{$\begin{array}{l}\text { Pengalaman } \\
\text { Mengikuti } \\
\text { Workshop }\end{array}$} & Ada & 23 & $79 \%$ \\
\hline & Tidak Ada & 6 & $21 \%$ \\
\hline \multirow[t]{2}{*}{ Status Sertifikasi } & $\begin{array}{l}\text { Sudah } \\
\text { Sertifikasi }\end{array}$ & 21 & $72 \%$ \\
\hline & $\begin{array}{l}\text { Belum } \\
\text { Sertifikasi }\end{array}$ & 8 & $28 \%$ \\
\hline \multirow[t]{2}{*}{ Status Guru } & Guru Tetap & 20 & $69 \%$ \\
\hline & Guru Honorer & 9 & $31 \%$ \\
\hline \multirow{3}{*}{$\begin{array}{l}\text { Lama Mengajar } \\
\text { di SLBN } 6 \\
\text { Jakarta }\end{array}$} & $<1$ tahun & 8 & $28 \%$ \\
\hline & $1-10$ tahun & 15 & $52 \%$ \\
\hline & $>10$ tahun & 6 & $21 \%$ \\
\hline
\end{tabular}

Adapun hasil kategorisasi pengetahuan dan sikap guru mengenai PPI adalah sebagai berikut

Tabel 2. Pengetahuan Guru mengenai Pembuatan PPI

\begin{tabular}{lll}
\hline Kategorisasi & Frekuensi & Presentase \\
\hline Kurang & 10 & $34 \%$ \\
Cukup & 17 & $59 \%$ \\
Baik & 2 & $7 \%$ \\
Jumlah & 29 & $100 \%$ \\
\hline
\end{tabular}

Berdasarkan tabel di atas, terlihat bahwa lebih dari setengah partisipan dalam penelitian ini dikategorisasikan cukup memiliki pengetahuan terkait dengan pembuatan PPI. Hal ini berarti bahwa lebih dari sebagian guru memberikan respon dengan cukup tepat setiap pertanyaan yang berkaitan dengan definisi PPI, prinsip dasar, tujuan, serta proses pembuatan PPI, serta komponen PPI yang dibutuhkan untuk siswa. Sementara 34\% atau setara dengan 10 individu masuk dalam kategorisasi kurang dan 7\% (2 individu) masuk pada kategorisasi baik dalam merespon pertanyaan terkait dengan pembuatan PPI. Selain data hasil kuesioner pengetahuan, terdapat pula data mengenai sikap guru terhadap pembuatan PPI.

Tabel 3. Sikap Guru terhadap Pembuatan PPI

\begin{tabular}{lll}
\hline Kategorisasi & Frekuensi & Presentase \\
\hline Kurang & 13 & $45 \%$ \\
Cukup & 13 & $45 \%$ \\
Baik & 3 & $10 \%$ \\
Jumlah & 29 & $100 \%$ \\
\hline
\end{tabular}

Berdasarkan tabel sikap guru terhadap pembuatan PPI, dapat terlihat bahwa sebanyak 45\% (13 orang) guru memaknai pembuatan PPI dengan cukup positif baik secara kognitif, afektif, maupun konatif. Setara dengan hal tersebut, sebanyak 13 dari 29 guru yang menjadi partisipan penelitian memaknai pembuatan PPI dengan kurang positif baik secara kognitif, afektif, dan konatif. Artinya, sebagian besar guru masih memiliki tingkat sikap yang bervariasi antara kurang dan cukup positif. Sementara itu, sebanyak 3 partisipan masuk dalam kategori baik terkait dengan sikapnya terhadap pembuatan PPI. Artinya, hanya sebagian kecil guru yang memiliki sikap positif terhadap pembuatan PPI. Pada penelitian ini, peneliti juga melihat gambaran sikap berdasarkan tiga dimensi sikap, yaitu dimensi kognitif, afektif, dan konatif. Hasil yang didapatkan sebagai berikut:

Tabel 4. Sikap Per Dimensi

\begin{tabular}{llll}
\hline & Kognitif & Afektif & Konatif \\
\hline Kurang & $45 \%$ & $48 \%$ & $41 \%$ \\
Cukup & $45 \%$ & $38 \%$ & $41 \%$ \\
Baik & $10 \%$ & $14 \%$ & $18 \%$ \\
Jumlah & $100 \%$ & $100 \%$ & $100 \%$ \\
\hline
\end{tabular}

Berdasarkan data di atas, dapat terlihat bahwa sebanyak 17 partisipan merasa kurang yakin bahwa pembuatan PPI merupakan hal yang penting untuk dilakukan. Hal yang sama terjadi pada partisipan yang merasa cukup yakin pada pembuatan PPI. Sementara itu, terdapat $10 \%$ 
partisipan masuk pada kategorisasi baik dalam bersikap secara kognitif terhadap pembuatan PPI.

Sementara itu, terdapat $48 \%$ partisipan masuk dalam kategorisasi kurang positif terkait dengan sikapnya secara afektif dalam pembuatan PPI. Artinya, partisipan pada kategori ini memiliki perasaan kurang positif terkait dengan pembuatan PPI. Sementara itu, 38\% dari keseluruhan partisipan masuk pada kategorisasi cukup positif. Tercatat pula bahwa $14 \%$ termasuk dalam kategori kurang terkait dengan sikapnya secara afektif dalam pembuatan PPI.

Dari dimensi konatif dapat terlihat bahwa terdapat $41 \%$ partisipan atau setara dengan 12 individu masuk dalam kategorisasi cukup positif terkait dengan sikapnya secara konatif dalam pembuatan PPI. Artinya, partisipan pada kategori ini memaknai perilaku pembuatan PPI dengan cukup positif. Hal yang sama juga terjadi pada guru dengan kategorisasi kurang positif, yaitu terdapat 12 individu yang juga memaknai perilaku pembuatan PPI dengan kurang positif. Selain itu, sebanyak $18 \%$ dikategorikan baik pada dimensi konatif sikap guru dalam pembuatan PPI. Artinya, individu pada kategori ini memaknai perilaku pembuatan PPI secara positif.

Selain hasil tersebut, hasil uji beda yang dianalisis dengan menggunakan teknik Independent T-test, menunjukkan bahwa terdapat perbedaan yang signifikan pada hasil uji beda yang telah dilakukan oleh peneliti pada kategori ada tidaknya pengalaman mengikuti workshop mengenai pengajaran siswa berkebutuhan khusus (Sig .02 $\leq .05)$. Hal ini bermakna bahwa terdapat perbedaan tingkat sikap antara guru yang memiliki pengalaman mengikuti workshop terkait dengan pengajaran siswa berkebutuhan khusus dengan guru yang tidak memiliki pengalaman tersebut.

\section{Hasil Penelitian Kualitatif}

Pada umumnya, guru-guru yang menjadi partisipan wawancara berpendapat bahwa pembuatan PPI merupakan hal yang penting untuk dilakukan. Mayoritas guru menyadari pentingnya pembuatan PPI, terutama dalam menentukan target dan mengetahui setiap perkembangan kecil siswasiswanya. Selain itu, guru-guru juga merasa bahwa setiap kemajuan siswa dapat tercatat dan hal ini dapat bermanfaat dalam pelaporan pada orangtua.
Akan tetapi, terdapat faktor pengalaman yang memengaruhi pembuatan PPI di SLBN X Jakarta ini. Salah satunya adalah kemampuan guru yang masih beragam dalam menentukan metode dan target siswa dapat menjadi penghambat pengerjaan PPI. Mayoritas guru juga merasa bahwa mereka tidak mengetahui bagaimana pembuatan PPI yang detail, tepat guna, dan bermanfaat bagi siswa. Meski pernah mempelajari pembuatan PPI saat masih kuliah dan memahami pemikiran dasar dalam pembuatan PPI, guru merasa bahwa mereka tidak mengetahui bagaimana prakteknya jika dilakukan di lapangan. Dalam hal ini, guru merasa membutuhkan format tertentu dan terdapat workshop khusus mengenai pembuatan PPI. Hal ini akan membantu guru dalam memahami dan menyusun PPI.

Saat ini, meski telah dicoba untuk melakukan modifikasi RPP untuk membagi pembelajaran pada beberapa kelompok siswa, guru merasa bahwa sosok kepala sekolah berperan dalam proses pembuatannya. Hal ini disebabkan peraturan mengenai pembuatan PPI ini pada dasarnya memang diberikan oleh pihak kepala sekolah. Selain itu, kepala sekolah juga dianggap belum memiliki cara yang tepat untuk memberikan kritik yang membangun pada pembuatan modifikasi program yang dibuat oleh guru.

Salah satu faktor pendukung yang dapat membantu adalah dengan adanya keberadaan pengawas dalam pembuatan PPI. Pengawas ini dapat menjadi sosok yang dapat diandalkan dalam berdiskusi dan menentukan kecocokan PPI. Guru berpendapat bahwa pihak sekolah belum pernah memberikan penambahan pengetahuan mengenai pembuatan PPI. Oleh karenanya, tidak ada pula kesempatan bagi guru untuk membuat PPI secara keseluruhan. Selain itu, dirasakan pula belum terdapat kewajiban baik dari pihak sekolah atau dari pihak pusat yang mengharuskan guru membuat PPI. Sebagian besar guru merasa jika memang sudah diwajibkan, maka mereka akan tetap membuatnya.

Secara umum, guru merasa faktor lain yang dapat sangat mendukung adalah dengan menjadikan pembuatan PPI sebagai hal yang wajib dilakukan. Hal ini masih menjadi penghambat karena berdampak pada guru-guru yang belum mengusahakan menyusun strategi (terutama dalam menyusun waktu) dalam pembuatannya. Faktor lain yang juga berperan adalah bahwa mayoritas 
DOI:

guru merasa pembuatan PPI membutuhkan waktu yang tidak sedikit. Hal ini menjadi penghambat bagi guru karena terdapat kewajiban dalam pembuatan administrasi lain dan kewajiban masing-masing guru di luar sekolah (seperti ibu rumah tangga atau menyelesaikan studi kuliah terbuka).

\section{Pembahasan}

Berdasarkan hasil penelitian, diketahui bahwa saat ini mayoritas tingkat pengetahuan guru SLBN X Jakarta mengenai pembuatan PPI berada dalam kategori cukup. Hal ini berarti bahwa sebagian besar guru memiliki pengetahuan memadai dalam membuat PPI baik dari segi dasar pembuatan PPI, perlunya asesmen yang dilakukan sebelum penulisan PPI, dan juga dalam menjalin kerjasama dengan pihak lain dalam rangka pembuatan PPI bagi masing-masing siswa. Sementara itu, terlihat pula bahwa mayoritas sikap guru terhadap pembuatan PPI masih berada pada tahap cukup positif.

Secara keseluruhan, tingkatan pengetahuan dan sikap ini masih bervariasi dan belum merata. Pengetahuan merupakan salah satu aspek penting dalam hidup manusia yang dapat mengarahkannya pada sebuah perubahan. Dalam hal ini, pengetahuan guru mengenai PPI dapat menjadi kunci adanya perubahan pada guru dalam pembuatan PPI yang juga diusung oleh UndangUndang terkait dengan modifikasi kurikulum. Sedangkan sikap guru terhadap PPI dapat berperan dalam menentukan dirinya berperilaku dalam kehidupan kesehariannya berhubungan dengan program bagi siswa yang diajarnya.

Eason (2006) menyatakan bahwa guru merupakan sosok yang penting dalam terciptanya penerapan PPI bagi siswa berkebutuhan khusus di sekolah. Peranan guru semakin menjadi penting di tengah keterbatasan sarana dan prasarana sebagaimana dialami oleh negara-negara berkembang (Heynemen \& Loxley, 1983). Hasil penelitian tersebut menunjukkan bahwa guru merupakan faktor yang dominan dalam menentukan prestasi belajar siswa. Sejalan dengan hal itu, hasil penelitian Arravey (dalam Lynch, 1994) menunjukkan bahwa efektivitas PPI juga dapat membuat siswa berkebutuhan khusus semakin bersemangat dalam menjalankan pembelajaran. Hal ini berarti, jika guru memiliki pengetahuan dan sikap yang positif terhadap pembuatan PPI maka dampak yang terasa akan terjadi pada siswa yang menjadi tanggung jawabnya.

Dari hasil penelitian, dapat diketahui bahwa tidak terdapat perbedaan variasi tingkat pengetahuan dan sikap guru SLBN X Jakarta terhadap PPI pada jenis kelamin, ada tidaknya pengalaman mengajar, status sertifikasi, status guru, usia, serta lamanya guru mengajar di SLBN X Jakarta. Hal ini berarti kecurigaan awal kepala sekolah mengenai status sertifikasi yang dapat memengaruhi sikap guru terhadap PPI tidak dapat ditegakkan. Sejalan dengan hal ini, Rahmayanti dan Anwar (2015) juga mengemukakan mengenai status sertifikasi pada guru yang masih menjadi persyaratan yang cenderung bersifat administratif. Meski memang dibuat sebagai bentuk apresiasi bagi guru dalam kinerjanya, isi kebijakan implementasi sertifikasi guru masih belum jelas karena belum dibuatnya aturan pelaksana di tingkat provinsi maupun kabupaten terkait tugas, fungsi, hak, kewajiban dan wewenang guru-guru yang sudah menjalani proses sertifikasi.

Di sisi lain, dapat terlihat bahwa variasi sikap positif guru terhadap PPI dipengaruhi oleh keiikutsertaan guru SLBN X Jakarta dalam mengikuti workshop. Secara detail, workshop yang diikuti merupakan workshop yang berkaitan dengan pembelajaran siswa berkebutuhan khusus. Beberapa guru pernah mengikuti pembelajaran penjaskes adaptif, pelaksanaan kurikulum 2013, pengenalan warna bagi siswa berkebutuhan khusus, hingga berhubungan dengan bina diri bagi siswa berkebutuhan khusus. Meskipun materi ini secara umum tidak berkaitan langsung dengan PPI, guru-guru yang mengikuti workshop ini sebagian besar merupakan guru yang mendapatkan materi tersebut dengan mewakilkan diri dari pihak sekolah. Oleh sebab itu, materi-materi yang berhubungan dengan kurikulum dan pembelajaran siswa berkebutuhan khusus berpatokan pada adanya modifikasi kurikulum yang merupakan ide dasar dari Undang-Undang Pendidikan No. 20 tahun 2003.

Sementara itu, dari segi detail komponen pada sikap, diketahui bahwa tidak terdapat korelasi yang signifikan antara pengetahuan dan sikap guru SLBN X Jakarta ketika berhubungan dengan pembuatan PPI. Hal yang sama terjadi pada hubungan antara pengetahuan dengan komponen 
kognitif, afektif, dan konatif pada sikap. Artinya, pengetahuan bukanlah satu-satunya penentu bagi guru SLBN $X$ Jakarta bersikap terhadap pembuatan PPI. Adapun hal ini berkaitan dengan implementasi yang telah dibayangkan oleh guru ketika mereka menyusun PPI bagi setiap siswanya. Guru SLBN X Jakarta merasa bahwa mereka tidak memiliki waktu yang cukup untuk menuliskan PPI setiap siswa yang menjadi tanggung jawabnya.

Hal menarik lainnya yang ditemui adalah berkaitan dengan kebutuhan akan sosok pengawas atau adanya kewajiban mengenai pembuatan PPI. Guru SLBN X Jakarta tergambarkan cenderung akan menuntaskan kewajiban jika hal tersebut diwajibkan secara tegas atau terdapat sosok yang dapat membantu dalam diskusi pembuatan PPI itu sendiri. Sejalan dengan hal ini, Cohen, Susan, dan Bailey (1997) dalam penelitiannya menjabarkan mengenai fungsi informasi yang diberikan di dalam kelompok. Dalam hal ini, anggota di dalam kelompok memiliki kecenderungan untuk berpengaruh secara sosial ketika berkaitan dengan adanya sosok leader yang berani beropini. Dalam hal ini, adanya sosok dalam pembuatan PPI di SLBN X Jakarta dapat membantu guru dalam pembentukan sikap karena sosok tersebut berguna dalam kecenderungan manusia untuk mendapatkan covalidation (pembenaran) akan ide-ide mengenai konsep PPI. Adanya sosok ini juga akan membantu guru untuk meningkatkan kesempatannya dalam membuat PPI.

Selain itu, didapatkan pula bahwa guru SLBN $\mathrm{X}$ Jakarta juga menyadari adanya kesenjangan pengetahuan yang mereka miliki terkait dengan pembuatan PPI. Berhubungan dengan hal ini, maka peningkatan pengetahuan mengenai pembuatan PPI dan materi-materi yang berhubungan dengan pembuatan PPI sangat diperlukan guru dalam mengaplikasikan pembuatan PPI bagi siswa berkebutuhan khusus. Dalam hal ini, guru juga tidak memahami pembuatan PPI secara konkrit karena mayoritas guru belum pernah menuliskan PPI secara langsung dan hanya mendapatkannya ketika masa perkuliahan. Sementara mayoritas guru di SLBN X Jakarta merupakan guru yang telah lama lulus dari masa perkuliahan. Berdasarkan pada faktor-faktor ini dapat diketahui bahwa adanya contoh pembuatan PPI serta pelatihan atau bimbingan teknis yang mengarahkan pada pembuatan PPI secara langsung dapat membantu guru untuk lebih memahami cara pembuatan PPI dan mempraktekkannya dalam proses belajar mengajar.

\section{KESIMPULAN}

Berdasarkan hasil penelitian, diperoleh kesimpulan bahwa mayoritas guru SLBN X Jakarta memiliki pemahaman yang cukup dalam memaknai dasar pembuatan PPI, tujuan pembuatan PPI, proses dalam pembuatan PPI, serta pemahaman mengenai komponen-komponen yang tertera pada PPI. Sementara secara umum sikap guru SLBN X Jakarta terhadap pembuatan PPI masih bervariasi antara kurang dan cukup. Hal ini menunjukkan guru-guru masih berada pada tahap kurang dan cukup positif dalam memberikan evaluasi secara kognitif, afektif, dan konatif pada prinsip dasar PPI, tujuan pembuatan PPI, asesmen yang dibutuhkan dalam proses pembuatan PPI, kerjasama dengan pihak lain dalam pembuatan PPI, keberadaan komponen-komponen PPI, serta sikapnya terhadap PPI secara menyeluruh.

Kesimpulan lain yang didapatkan adalah bahwa guru mengetahui pentingnya pembuatan PPI bagi siswa berkebutuhan khusus, yaitu untuk memfasilitasi keberagaman siswa dan sebagai bahan dokumentasi kondisi kemajuan siswa agar dapat terkontrol dengan lebih baik. Akan tetapi, fakta bahwa guru-guru belum memahami pembuatan PPI dikatakan langsung oleh beberapa guru. Selain itu, pembuatan PPI dirasa guru akan membutuhkan alokasi waktu lebih banyak bagi mereka. faktor penghambat bagi guru dalam menentukan sikapnya.

Selain itu, guru SLBN X Jakarta merasa bahwa pembuatan PPI dapat ditunjang dengan adanya kewajiban akan pembuatan PPI itu sendiri. Meski terkesan sulit dalam mengalokasikan waktu, adanya kewajiban dari pihak sekolah atau pihak berwenang lainnya dapat membantu dalam guru mengusahakan pembuatan PPI. Hal lain yang juga memudahkan adalah adanya format pembuatan PPI serta penambahan pengetahuan mengenai pembuatan PPI yang efektif.

Berdasarkan hasil penelitian secara keseluruhan, saran yang dapat diberikan kepada SLBN $X$ adalah berhubungan dengan adanya perbaikan sistem mengenai pembuatan PPI. Hal ini dapat dilakukan dengan perancangan format PPI yang kemudian disosialisasikan kepada guru-guru 
DOI:

SLBN X. Sosialisasi ini dapat membantu dalam peningkatan pengetahuan dan sikap guru berkaitan dengan pembuatan PPI. Langkah lain dalam peningkatan sikap adalah dengan adanya sosok dominan yang berperan dalam penentuan kewajiban guru dalam pembuatan PPI di SLBN X. Hal ini dapat dilakukan oleh pihak kepala sekolah yang dapat bekerjasama dengan pihak lain yang dirasa memenuhi kriteria tersebut. Selain itu, adanya jadwal rutin bagi guru untuk membahas mengenai pengetahuan yang berkaitan dengan pendidikan bagi siswa dibutuhkan guna meratakan pemahaman terbaru mengenai pembelajaran bagi siswa di SLBN X.

\section{DAFTAR PUSTAKA}

Aronson, E., Wilson, T. D., \& Akert, R. M. (2007). Social psychology. New York: Pearson Prentice Hall.

Child Trends Data Bank. October 2015. IEP: Indicators on children and youth. Diakses online $\begin{array}{lllll}\text { pada } & 16 & \text { Februari } & 2018 \quad \text { di }\end{array}$ https://www.childtrends.org/.

Canada Ministry of Education. (2004). The IEP, a resource guide. Diakses online pada 13 Februari 2018 di http://www.edu.gov.on.ca/.

Cohen, S. G. \& Bailey, D. (1997). What makes teams work: Group effectiveness research from the shop floor to the executive suite. Journal of Management, 23, 239-290.

Creswell, J. W. (2014). Research Design: Qualitative \& quantitative approaches. Thousand Oaks Calif: Sage Publications.

Dikdasmen Nomor 10 tahun 2017. Pedoman implementasi kurikulum 2013 pendidikan khusus. Terbit pada 4 April 2017. Diakses pada 2 Juli 2018.

Direktorat PLB. (2004). Pedoman penyelenggaraan pendidikan terpadu/inklusi pengembangan kurikulum, I Dirjen Pendasmen, Depdiknas, Jakarta.

Eason, A. I. \& Whitebread, K. (2006). IEP and inclusion tips for parents and teachers. Wiconsin, Verona: Attainment Publication. Diakses online pada Februari $2018 \quad$ di http://www.faslink.org/ieptips.pdf.

Epstein, R. M., \& Hundert, E.M. (2002). Defining and assesing professional competence. Journal of the American Medical Association, 287,226-235

Fabrigar, L. R., MacDonald, T. K., \& Wegener, D. T. (2005). The structure of attitudes. In D. Albarraci'n, B. T. Johnson, \& M. P. Zanna (Eds.), Handbook of attitudes and attitude change (pp. 79124). Mahwah, NJ: Erlbaum.

Hermanto. (2010). Penyelenggaraan pendidikan inklusif membutuhkan keseriusan manajemen sekolah. Jurnal pendidikan Khusus Vol 6, No.1 Mei 2010, hal 65-81. Yogyakarta: Jurusan Pendidikan Luar Biasa FIP UNY.

Heynemen, S. P. \& Loxley, W. A. (1983). The effect of primary-school quality on academic achievement across twenty-nine high and low income countries. American Journal of Sociology Vol. 88, No. 6 (May 1983), 1162- 1194.

Kaslow, N. (2014). Competencies in professional psychology. American psychologist journal November 2014, hal: 774-781. Diunduh pada Januari 2018 di https://www.researchgate.net.

Lynch, J. (1994). Projection for children with special need education in Asian Region. USA: The World Bank.

Mangunsong, F. (2009). Psikologi dan pendidikan anak berkebutuhan khusus. Depok: LPSP3 UI.

Mercer, C. D. \& Mercer, A. R. (1989). Teaching student with learning problems. Aus: Merill Publishing Company A Bell \& Howel Information Company.

Notoatmodjo, S. (2003). Pendidikan dan Perilaku Kesehatan. Jakarta: PT Rineka Cipta.

Rahmawati, K. N. (2015). Pengembangan program peningkatan kompetensi guru dalam menyusun program pembelajaran individual di SLB aditya grahita kota bandung. Repository Universitas Pendidikan Indonesia. Diakses pada Februari 2018 di www.repository.upi.edu.

Rahmayanti, E. \& Anwar, K. (2015). Implementasi Kebijakan Sertifikasi Guru Sekolah Dasar Di Kecamatan Keritang Kabupaten Indragiri Hilir Tahun 2012. Jom FISIP Vol. 2, No.1 Februari 
DOI:

2015. Diakses online pada Maret 2018 di http://jom.unri.ac.id.

Rochyadi, E. (2001). Penerapan program pembelajaran individual bagi anak tunagrahita. Jakarta: Direktorat Jenderal Pendidikan Tinggi Departemen Pendidikan Nasional.

Rochyadi \& Alimin Z, (2005). Pengembangan program pembelajaran individual bagi anak tunagrahita. Jakarta: departemen pendidikan nasional. Direktorat Jenderal Pendidikan Tinggi. Direktorat P2TK dan KPT.

Rudiyati, S. (2010). Pengembangan dan pengelolaan program pendidikan individual bagi anak di sekolah inklusif. Jurnal pendidikan Khusus Vol 6, No.1 Mei 2010, hal 54-64. Yogyakarta: Jurusan Pendidikan Luar Biasa FIP UNY.

Sunanto, J., Rudiyati, S., Taboer, A., \& Damanik, T. (2013). Dokumen kerja: pendidikan individu dengan hambatan majemuk. Indonesia: Helen Keller International Indonesia

The Statement and Framework for Action on Special Needs Education. Diadaptasi dari The World Conference on Special Needs Education [microform]: Access and Quality (Salamanca, Spanyol, Juni 7-10, 1994).

Thompson, P., Thomas, L.J.D., Gunter, S. J. \& Bailey, J. (2013). The Role of Functional Skills Instruction. Diakses online pada Maret 2018 di https://www.lynchburg.ed.

Undang-Undang Republik Indonesia Nomor 20 Tahun 2003. Tentang Sistem Pendidikan Nasional.

Wawan, A. \& Dewi M. (2010). Teori dan pengukuran Pengetahuan, Sikap dan Perilaku Manusia. Yogyakarta: Nuha Medika. 